\title{
USING STUDENTS TO SUPPORT FACULTY DEVELOPMENT
}

Teresa M. Redd, Carl E. Brown Jr., Howard University

Howard University's Center for Excellence in Teaching, Learning, and Assessment (CETLA) provides faculty development for more than fifteen hundred faculty. Yet it is CETLA's students who make the difference. They are both the motivation for improving teaching and the means to that end. Students have contributed to everything from the design of CETLA's infrastructure, to the implementation of instructional technologies, to the assessment of student learning. Meanwhile, supporting faculty development has contributed to the students' own development. A cost-benefit analysis as well as survey data confirms that working with students at CETLA is a win-win opportunity for the university, faculty, students, and CETLA.

The faces of dozens of students adorn the southern wall of the Center for Excellence in Teaching, Learning, and Assessment (CETLA) at historically black Howard University. These are the faces of CETLA's student assistants. Although CETLA is a faculty development center, students play an indispensable role by motivating and facilitating faculty development. In fact, without its student employees and collaborators, CETLA could not address the pedagogical needs of Howard's faculty in its twelve schools and colleges, and the students, faculty, and university would not reap the unique benefits of CETLA's student partnership.

According to its mission statement, CETLA is "dedicated to developing a cadre of faculty who will produce distinguished and compassionate leaders to serve the nation and the global community. Through faculty training, instructional technology, interdisciplinary collaboration, classroom assessment, and educational research, CETLA strives to ensure that students gain an educational experience of exceptional quality" (Center 
for Excellence in Teaching, Learning, and Assessment, 2007). Consequently CETLA offers a wide range of workshops, seminars, online tutorials, video-streamed lectures, distance learning courses, and Webbased resources to improve the faculty's teaching with and without technology. To fulfill its mission, CETLA requires a large, skilled staff. Currently it has a permanent staff of five, two instructors, the director, and the assistant director. CETLA has been recruiting, training, and collaborating with students since it opened in October 2003.

Engaging students in faculty development is not new. Since 1996, the national GenerationYES! program has been training K-12 students to help teachers, preservice teachers, and education faculty integrate technology into the curriculum (Generation Yes Youth and Educators Succeeding, 2007). Nevertheless, we found relatively few publications about student assistant programs at faculty development centers on college and university campuses. Our literature review, Web search, and survey of Howard's peer and neighboring institutions (Table 17.1) confirmed that a number of centers hire students to assist with faculty development, but primarily as clerical and research assistants.

Table 17.1 Telephone Survey of Selected Faculty Development Centers

\begin{tabular}{|c|c|c|}
\hline Institution & Student Assistants? & Primary Duties \\
\hline George Mason University & Yes & Assist with accreditation \\
\hline Georgetown University & Yes & $\begin{array}{l}\text { Assist with training and } \\
\text { research }\end{array}$ \\
\hline $\begin{array}{l}\text { George Washington } \\
\text { University }\end{array}$ & Yes & Perform clerical work \\
\hline Marymount University & Yes & $\begin{array}{l}\text { Perform clerical work, } \\
\text { video recording, and } \\
\text { develop Web pages }\end{array}$ \\
\hline Morehouse College & Yes & $\begin{array}{l}\text { Assist with administra- } \\
\text { tive work }\end{array}$ \\
\hline $\begin{array}{l}\text { North Carolina } A \& T \\
\text { University }\end{array}$ & No & \\
\hline University of Maryland & Yes & Assist with training \\
\hline University of Virginia & Yes & Perform clerical work \\
\hline Xavier University & Yes & Perform clerical work \\
\hline
\end{tabular}


Centers at Georgetown University and the University of Maryland, College Park reported that they engage students in some teaching-learning activities, namely training faculty to use instructional technology. In addition, we identified several centers that recruit students to assist faculty with other types of teaching-learning activities:

- Course design: Michigan State University assigns graduate students to help faculty design distance learning sites. As a result, the students and faculty have not only learned new technologies but gained valuable insights: faculty have considered the design of their courses from a student perspective, while the students have discovered why faculty design courses as they do (Mishra, Koehler, Hershey, \& Peruski, 2002).

- Role playing: The University of Illinois, Chicago enlists students to improve clinical teaching skills by portraying students in challenging classroom scenarios (Gelula \& Yudkowsky, 2003). Like standardized patients in medical schools, these students are trained to act, speak, and respond in a consistent manner as they interact with faculty.

- Student observer programs: Several institutions hire and train students to attend a faculty member's classes and discuss their observations with the faculty member in order to improve teaching and learning in the course. Some examples are found at Brigham Young University (Brigham Young University, 1997), Carleton College (Carleton College: Learning and Teaching Center, 2008), Dickinson College (Laws, 1977), and the University of Toledo (University of Toledo Center for Teaching and Learning, 2009).

However, our findings suggest that the role of students at CETLA is noteworthy. At CETLA, we have integrated students into a wide range of activities as a cost-effective means of meeting our faculty's professional development needs. At the same time, through mentoring and peer teaching, we have succeeded in meeting many of our students' needs. Thus, our center has become a teaching and learning center for our students as well as our faculty.

\section{Hiring}

While students contribute to CETLA through collaboration, employment is the primary means. Each year we employ approximately ten students who work ten to twenty hours a week. In the summer, half of the 
students work on projects off-campus, for a total of forty hours for the entire summer.

To recruit students, we e-mail advertisements to the chairs of departments in the Schools of Engineering, Education, Business, and Communications and the College of Arts and Sciences. We also submit ads to the office of financial aid. However, the most successful recruiters are our current student assistants, who gladly refer their classmates and friends. Applicants e-mail their résumés to CETLA, come to CETLA for interviews, and for video, Web, and research positions, they submit samples of their work.

After vetting the candidates, we offer one of four types of compensation: wages, tuition, federal work-study funds, or internship credit. Most of our student employees receive wages or tuition from the student aid pool of CETLA's budget. Over the years, we have transferred an increasing amount of funds from our equipment pool to the student aid pool, so that student aid now represents more than 15 percent of our annual budget. However, sometimes we do not have to pay at all. For example, if a qualified work-study student applies, the federal government covers the cost. And if the student can earn academic credit for a CETLA internship, the student may work free of charge.

\section{Positions and Responsibilities}

Once hired, students assume critical roles in CETLA's infrastructure, as the following job descriptions reveal:

- Webmaster: Designs, posts, and updates content on CETLA's website; takes photographs as needed.

- Video editor: Videotapes guest lectures, guest workshops, keynote speeches, classroom teaching, and special events; edits and publishes videos for streaming.

- Programmer (replaced by a full-time staff member in 2007): Builds databases, writes database queries, generates database reports, and troubleshoots to resolve database errors.

- Instructional technology assistant: Helps faculty keep up with their colleagues during technology workshops; provides one-on-one, hands-on assistance during open labs; visits faculty offices to teach a five-minute "Blackboard Basics" tutorial; shows faculty how to digitize course materials using CETLA's equipment; assists CETLA's staff with technology projects. 
- Lab assistant: Sets up computers, peripherals, and networking; fixes computers; loads software.

- Course redesign assistant: Creates digital media (for example, animation, video, or Web page) for faculty who have completed CETLA's Course Redesign Seminar.

- Research assistant: Conducts bibliographical and Web searches; collects, analyzes, and summarizes data for CETLA's assessment, annual reports, presentations, and publications.

- Clerical assistant: Files documents, updates CETLA's sign-in database, delivers mail, and performs other office duties as assigned.

Regardless of their position, student employees are eligible to participate in CETLA's Faculty Resource Network Database (FRieND) Program, which permits faculty mentors to redeem their mentoring hours for time-saving student services through a system called time-banking (TimeBanks, n.d.) For example, in exchange for one hour of mentoring, a mentor can earn an hour of clerical, research, or technology services from CETLA's student employees, such as scanning documents, posting materials online, searching the Web for multimedia resources, or compiling a bibliography from scholarly databases.

Occasionally we assign students tasks that extend beyond their job descriptions so that they can use what they have learned in their major field of study. Consequently we have asked a broadcast major to do a voice-over for a tutorial, a journalism major to interview and write about the featured teacher of the month, and a biology major to introduce an online lab report program to biology teaching assistants. We also have assigned tasks to advance students' learning in their major. For example, we showed a psychology major how to use SPSS to analyze CETLA's "real-world" data; as a result, the student reported that she had gained greater confidence in her introductory SPSS class. Indeed, one survey respondent urged us, "Keep doing what you are presently doing. Challenge your present student employees-give them a chance to do something out of their comfort zone."

Whenever possible, we also assign students to workshops or projects for their own departments. Such assignments allow them to use their knowledge of the discipline to assist their professors and reap the benefits of what their professors learn at CETLA. For instance, we assigned an electrical engineering major to help her professors during a departmental Blackboard workshop. Another time we asked a pharmacy student for assignments and feedback to help us design a workshop for the pharmacy 
faculty. On another occasion, we asked a psychology major to find writing guides that her professors could share with their psychology classes.

Finally, we encourage all of our student employees to reflect on what they are doing at CETLA, what is happening in their classrooms, and what CETLA can do to improve teaching and learning. As one survey respondent observed, "A student employee brings a fresh perspective to all activities of the center." After all, our student employees are students first, with a keen understanding of what their peers like and understand. Who is better qualified to think of questions for our Blackboard FAQs for Students page, recommend raffle prizes for a student survey, or determine how helpful a chemistry simulation is? Therefore, although we do not sponsor a student observer program, we seek student opinions about the technologies and strategies that we introduce to the faculty. If student assistants find an innovation confusing, hard to use, or boring, we want to know. As another survey respondent observed, a "student's perspective ... can be invaluable in separating what works from what does not."

\section{Training}

Before they can start working in their new positions, students must attend an orientation conducted by Howard's human resource department. Afterward they complete our online orientation to CETLA's policies and procedures. The online orientation is a self-scoring Blackboard mastery quiz, designed by CETLA students as well as staff to be both humorous and informative. To achieve mastery of the policies and procedures, students must repeat the quiz until they have earned at least 80 percent.

While some students bring valuable skills to CETLA, others bring mainly an aptitude for learning. Therefore, we require students to attend our faculty workshops whenever their schedules permit and to watch our online video tutorials. We also ask current CETLA student assistants to train new students, for instance, teach them how to use the self-service digitization station or how to update our sign-in database. What has pleasantly surprised us is how much peer teaching has occurred extemporaneously. For instance, on their own, the video editor has taught the webmaster to edit videos, and the webmaster has taught the video editor to develop Web pages; the programmer has taught the webmaster to embed code, and the webmaster has taught the programmer to design a better user interface. Without being asked, instructional technology assistants have helped one another master the art of constructing Blackboard tests, PBworks wikis, and SurveyMonkey surveys. Even our full-time staff members have learned from students. For example, from watching and 
working with students, our full-time programmer has become a backup webmaster and cameraman.

\section{Student Collaboration}

While CETLA has employed students, it has also sought to collaborate with students outside the center on special projects, especially projects involving art, assessment, and awards. These projects demonstrate how a teaching and learning center can support teaching and reward learning in diverse ways.

Shortly after CETLA opened in 2003, it collaborated with an electronic studio class in the department of art to design the center's logo. During one class period, CETLA's director presented CETLA's mission, goals, and objectives. Later she visited the class to view students' drafts and answer questions. Finally, after reviewing the designs with CETLA's staff, she returned to the classroom to present awards for first, second, and third place. In 2009, CETLA turned once again to students in the department of art to submit their digital artwork for a perpetual slideshow in CETLA's computer classroom. CETLA hoped that the artwork would not only decorate the sterile-looking room but also give the art students' work exposure in CETLA's digital art gallery.

For one of its most successful ventures, CETLA enlisted a graduate class to assess the impact of CETLA's faculty training. Beginning in spring 2008, CETLA began collaborating with the professor and graduate students in a course entitled Effective Use of Technology in Teaching and Learning. Through its partnership with the class, CETLA provided graduate assistants (who were students in the course) for five faculty members to conduct classroom assessment research, which supplied the data for the graduate students' term projects. At the beginning of the term, CETLA introduced the graduate students to resources on teaching with technology, taught a hands-on workshop on survey construction, created a survey item bank based on Chickering and Gamson's (1987) "Seven Principles of Good Practice in Undergraduate Education," and then matched the students with CETLA-trained faculty who were implementing new strategies or technologies. CETLA also assigned one of its own graduate student employees to assist the instructor and students in the course. With the graduate students' support, faculty pursued the following projects: a biology professor assessed the effectiveness of Blackboard in his molecular biology class; a physics professor assessed the effectiveness of cumulative quizzes compared with collaborative learning in a calculus-based physics course; another biology professor assessed 
students' perceptions of the benefits of multimedia as a tool for learning biology; a chemistry professor assessed students' learning through weekly online surveys so that he would know whether he needed to review any concepts the next week; and a medical professor assessed student satisfaction with her current use of Blackboard and solicited the students' recommendations for other uses. Without student collaboration, CETLA would not have been able to conduct so many studies. Although there were methodological weaknesses in some of the studies, three of the five studies were robust enough to cite in CETLA's annual assessment report.

CETLA has also recruited students to participate in deliberations about its teaching awards. Believing that student evaluations of teaching are essential, CETLA has invited student members of the teaching, learning, and technology committee to serve alongside faculty as judges who review applications for CETLA's annual Teaching with Technology Award. CETLA has also asked its student employees to rate syllabi submitted for CETLA's annual Exemplary Syllabus Award.

\section{Limitations}

Despite the benefits, student employment and collaboration have their limits. First, with the ebb and flow of matriculation and graduation, student turnover is high. Whenever we can, we hire sophomores and juniors so that they can work two or three years at CETLA, developing greater expertise and enjoying greater financial security. Since we need an experienced video editor, we have established an apprenticeship to address the turnover problem: each year we hire a junior and a senior video editor. The junior video editor must make a two-year commitment to train as an apprentice under the senior video editor during the first year so that he or she can take over when the senior video editor graduates.

Second, since our students' academic progress takes priority, we have to schedule workshops, videotaping, and open labs around our students' schedules, making sure that the students have enough time to go to class and to study. In fact, the university will not allow full-time students to work more than twenty hours a week or to hold more than one on-campus job. To facilitate scheduling, we teach instructional technology assistants how to use as many applications as possible so that they can substitute for one another if needed. Full-time staff members are also prepared to substitute.

Third, despite their talents and skills, we cannot allow students to perform certain tasks because of security concerns. For instance, even the most trustworthy clerical assistant is not permitted to log into PeopleSoft 
to submit requisitions, complete the department's timesheet, or create job openings. Sometimes our programmer can assign students to roles that limit their access within a database. However, certain students require unrestricted access. Thus we eventually decided to hire a full-time staff member as a programmer.

Fourth, like security, privacy is also a concern. We restrict students' access to data such as course evaluations, interview transcripts, and grades unless permission has been granted. Indeed, depending on the project, we have required some of our research assistants to earn certification from the Institutional Review Board by completing a series of online modules.

Fifth, many of our students create digital works of art, such as videos, animations, and graphics. Whenever appropriate, we list students' names in the credits. Nevertheless, we require students (as well as faculty collaborators) to sign copyright and performance releases. These releases give CETLA the right to disseminate the media but permit students to include the digital media in their portfolios for subsequent employment or graduate admission.

\section{Assessment}

CETLA anonymously surveyed its thirty-nine current and former student employees, and twenty-five responded (Exhibit 17.1 shows the survey).

\section{Exhibit 17.I Survey of Former and Current Student Assistants}

1. In what year did you begin working for CETLA?

2. If you no longer work at CETLA, in what year did you stop?

3. What is your gender?

4. Which program were you in while working at CETLA?

5. How many hours do or did you work at CETLA?

6. What is or was your position at CETLA?

7. The money I earned at CETLA helped me stay at Howard University.

8. While working at CETLA, I developed professional work habits.

9. While working at CETLA, I learned skills that helped me academically at Howard University.

10. I developed skills at CETLA that can help me prepare for a job or graduate/ professional school.

11. While working at CETLA, I developed a sense of pride in helping others (faculty or CETLA staff). 
12. While working at CETLA, I developed a sense of satisfaction in improving teaching at Howard University.

13. I would recommend working at CETLA to other students.

14. Please list the skills you have developed while working at CETLA.

15. Please list any skills or projects (including internships) you have developed at CETLA for academic credit.

16. Explain your attitude toward the faculty you have encountered at CETLA.

17. What insights as a student employee do you contribute to faculty development?

Of the survey respondents, 88 percent confirmed that supporting faculty development at CETLA had contributed to their own academic and professional development. According to the survey, students acquired technical skills such as shooting videos, adjusting lighting, video editing, photographing, developing Web pages, creating animations, building wikis, generating statistical analyses using SPSS, and constructing Blackboard course sites. Students also cited gaining project management, research, communication, presentation, time management, organizational, teaching, and interpersonal skills. In addition, they credited CETLA with enhancing their problem-solving and analytical thinking and helping them develop a "good work ethic." Some students considered the CETLA staff role models. As one survey respondent stated, they were "great leaders of the Center, very professional and driven by the goals of achieving excellence." On a personal note, another student wrote, "Thank you so very much for your guidance. You have allowed me to watch a very powerful, influential, and still very gentle black woman for the first time in my life!" Yet another student delivered a card saying, "It has been inspiring to see you perform in something to which your passion . . . is so innately tied. I hope I can one day say I am doing the same."

Of the twenty-five survey respondents, 88 percent reported that they had learned skills at CETLA that helped them academically at the university. Several of our video editors earned internship credit from the department of radio, TV, and film for taping and editing our guest lectures. A student programmer presented a database he created for CETLA as his term project in his information systems class. Not only did such skills prove helpful at Howard, but 92 percent of respondents felt that the skills they had acquired at CETLA prepared them for a job or graduate or professional school. It is also worth noting that numerous students have received production credits and developed artifacts for their portfolios. Even more have earned letters of recommendation from CETLA's staff confirming their productivity and professionalism. No wonder all of CETLA's student 
employees reported that they would recommend employment at CETLA to other students.

In addition to these benefits, 88 percent of the survey respondents agreed that working at CETLA had given them "a sense of satisfaction in improving teaching at Howard University," and 92 percent agreed that they had "developed a sense of pride in helping others" at CETL.A. One student wrote, "I believe that I was empowered as a student employee to serve the faculty and vice versa." Two students reported that they had gained greater respect for Howard faculty because of the faculty's "desire to improve" or "drive" to teach. Only one student said that some faculty assumed that the student assistants were "inadequate," and even that student conceded that many other faculty did not hold such assumptions. Other students said they appreciated the opportunity to help fellow students by helping professors. "I was able to understand their point of view and combine it with the wants and needs of my peers," one recalled. Another remarked on the experience of sharing "what faculty need to know to better communicate with their students." Yet another explained, "You help the faculty understand the student perspective. ... For example, its [sic] good for us at CETLA to encourage the usage of multimedia and graphics on a Blackboard site in order to more fully engage those students." In addition, two students noted that they had improved their own teaching skills, for instance, the "ability to explain things to others."

As this feedback reveals, the students credited CETLA staff and peers with modeling positive behaviors, helping them academically, preparing them for careers, and developing their life skills in a friendly and caring atmosphere. In short, CETLA provides most of the benefits of mentoring identified in Jacobi's (1991) review of the literature. These are not typical supervisor-employee, teacher-student, coworker, or classmate relationships. CETLA staff and students seek to help students improve their lives, not simply finish an assignment. For example, when training students to assist with a faculty workshop on wikis, one staff member showed students how they could use a wiki to apply for a job or graduate school or to coordinate teamwork. Likewise, a staff member training a student for a blog workshop helped her set up a blog to publish her creative writing. As Jacobi explains, "Whereas a traditional supervisor or teacher helps the employee or student to perform specific tasks correctly ... the mentor typically helps the protégé achieve longer term, broader goals" (p. 513). Perhaps that is why so many of CETLA's student employees maintain contact with CETLA staff and students for years after they graduate. 
In addition to the benefits derived by CETLA's student assistants and collaborators, annual workshop and customer service evaluations confirm that faculty benefit from the one-on-one assistance and expertise of CETLA's student assistants. On these anonymous surveys, faculty members report that the students are helpful, efficient, polite, and knowledgeable. But is such student participation cost-effective?

Clearly student employment is cost-effective for CETLA. A comparison with 2009 wages in the Washington, D.C., area (CBsalary.com, n.d) reveals that CETLA saves more than seventy thousand dollars per fiscal year by hiring students as opposed to nonstudent wage employees. The greatest savings stem from hiring students as webmasters and video editors. Moreover, survey results suggest that student employment is also cost-effective for the university as a whole. Nearly two-thirds (64 percent) of the twenty-five respondents agreed that the money they earned at CETLA helped them stay in school. CETLA rarely pays full tuition (or the equivalent in wages), and most CETLA students rely on a scholarship or pay the balance of their tuition out of their own pockets. Thus, without funding from CETLA, many students might drop out of school, depriving the university of revenue.

\section{Conclusion}

Our study suggests that CETLA's partnership with students has produced a win-win situation. It is a cost-effective model that benefits Howard University, CETLA, faculty, and students, and it could benefit other institutions. While CETLA enjoys access to students in specialized fields, such as engineering and film, we believe our model is feasible even for centers at small liberal arts colleges that do not offer such majors. Over the years, we have discovered that students often bring unexpected skills and aptitudes from other majors. For instance, an English graduate student became our first webmaster, a health sciences major became our Blackboard expert, and a psychology major became our statistician. If money is an obstacle, we believe that our model can meet that challenge as well. Most centers without budgets or grants to cover student employment can still recruit federal work-study students and student interns. Also, collaborating with classes, as we did for our assessment studies, can provide student support for a center's technology and research projects. We strongly recommend that teaching and learning centers, especially those that are struggling with staff shortages and lean budgets, consider students not only as the reason but as a resource for faculty development. 


\section{REFERENCES}

Brigham Young University. (1997). Brigham Young University Faculty Center. Retrieved from http://lamar.colostate.edu/ ckfgill/publ/progd/brigham.html Carleton College Learning and Teaching Center. (2008). Student observer program. Retrieved from http:/apps.carleton.edu/campus/ltc/services/observers/

CBsalary.com. (n.d.). Salary calculator. Retrieved from www.cbsalary.com /salary-calculatoraspx

Center for Excellence in Teaching, Learning, and Assessment. (2007). Mission. Retrieved from www.cetla.howard.edu/about/mission.html

Chickering, A. W., \& Gamson, Z. (1987). Seven principles of good practice in undergraduate education. AAHE Bulletin, 39, 3-7.

Gelula, M. H., \& Yudkowsky, R. (2003). Using standardized students in faculty development workshops to improve clinical teaching skills. Medical Education, 37(7), 621-629.

Generation Yes Youth and Educators Succeeding. (2007). Summary of Gen YES Rescarch. Retrieved from http://genyes.com/programs/genyes/research

Jacobi, M. (1991). Mentoring and undergraduate academic success: A literature review. Review of Educational Research, 61(4), 505-532.

Laws, K. (1977). A classroom observer program. Liberal Education, 6.3(1), 37-43.

Mishra, P., Koehler, M. J., Hershey, K., \& Peruski, L. (2002). With a little help from your students: A new model for faculty development and online course design. Retrieved from www.punyamishra.com/publications /proceedings/PM_MK_KH_LP_SITE.pdf

TimeBanks. (n.d.). History and structure. Retrieved from www.timebanks.org /history-structure.htm

University of Toledo Center for Teaching and Learning. (2009). Student observer program. Retrieved from www.utoledo.edu/centers/ctl/observer findex.html 